\title{
SYNCHRONIZING THE in vitro GERMINATION OF Psidium guineense Sw. SEEDS BY MEANS OF OSMOTIC PRIMING ${ }^{1}$
}

Márcia Adriana Carvalho dos Santos ${ }^{2 *}$, Mailson Monteiro do Rego ${ }^{3}$, Manoel Abilio de Queiroz ${ }^{4}$, Bárbara França Dantas ${ }^{5}$ and Wagner Campos Otoni ${ }^{6}$

\footnotetext{
${ }^{1}$ Received on 26.11.2014 accepted for publication on 24.05.2016.

${ }^{2}$ Universidade Federal da Paraíba, UFPB, Programa de Pós-Graduação em Agricultura Tropical, Areia, PB - Brasil. E-mail: <marciagro3@yahoo.com.br>.

${ }^{3}$ Universidade Federal da Paraíba, Centro de Ciências Agrárias, Laboratório de Biotecnologia Vegetal, Areia, PB - Brasil. E-mail:<mm.rego@hotmail.com>.

${ }^{4}$ Universidade do Estado da Bahia, Departamento de Tecnologia e Ciências Sociais-DTCS, Juazeiro, BA - Brasil. E-mail: $<$ manoelabiliomaq@gmail.com>.

${ }^{5}$ Empresa Brasileira de Pesquisa Agropecuária, Centro de Pesquisa Agropecuária do Trópico Semi-Árido, Petrolina, PE Brasil. E-mail: <barbara.dantas@embrapa.br>.

${ }^{6}$ Universidade Federal de Viçosa, Centro de Ciências Biológicas e da Saúde, Departamento de Biologia Vegetal, Viçosa, MG - Brasil. E-mail:<wcotoni@gmail.com>.

*Corresponding author.
}

\begin{abstract}
The Brazilian guava (Psidium guineense Swartz) is seed-propagated and, being native to the Caatinga biome, may frequently have uneven germination. Thus, we aimed to evaluate the synchronization of the in vitro seed germination of three accessions of the Brazilian guava, using water, polyethyleneglycol (PEG 6000), and potassium nitrate $\left(\mathrm{KNO}_{3}\right)$ at different potentials and times of osmotic priming. Seeds from three accessions of the Brazilian guava (Y85, Y93, and Y97) from the UNEB/BA Germplasm Active Bank were subjected to the following pretreatments: $-0.6,-1.0,-1.4$, and $-1,8 \mathrm{MPa}$ PEG $6000 ; 10$ and $20 \% \mathrm{KNO}_{3}$ for $24 \mathrm{~h} ; 10$ and $20 \% \mathrm{KNO}_{3}$ for $48 \mathrm{~h}$; water for 24 and $48 \mathrm{~h}$; and non-primed seeds as the control. The experimental design was therefore a $10 \times 3+1$ factorial scheme. We assessed the germination percentage (G), mean germination time (MGT), germination speed (GS), and germination speed index (GSI). Data was subjected to analysis of variance followed by a means test (Duncan at $5 \%$ probability) and regression. There was interaction between the priming treatments and accessions for all evaluated features, except G. PEG 6000 decreased the MGT (from 6 to 8 days) and increased GS and GSI of seeds from all three accessions at potentials -1.0 to -1.5 $\mathrm{MPa}$.Water-priming had a positive effect on MGT, GS, and GSI of accession Y85 seeds. $\mathrm{KNO}_{3}$ negatively affected germination of seeds from all three accessions. Thereby, we could synchronize seed germination of accessions Y85 and Y97 with PEG 6000.
\end{abstract}

Keywords: Caatinga; Brazilian guava; Germination.

\section{SINCRONIZAÇÃO DA GERMINAÇÃO DE SEMENTES DE Psidium guineense Sw. in vitro USANDO CONDICIONAMENTO OSMÓTICO}

\begin{abstract}
RESUMO - O araçá (Psidium guineense Swartz) é propagado por sementes e por ser uma espécie silvestre da Caatinga pode apresentar desuniformidade na germinação. Assim, objetivou-se avaliar a sincronização da germinação in vitro de sementes de três acessos de araçá, utilizando-se água, polietilenoglicol (PEG 6000) e nitrato de potássio $\left(\mathrm{KNO}_{3}\right)$ em diferentes potenciais e tempo de condicionamento osmótico. Sementes de três acessos de araçá (Y85, Y93 e Y97) do Banco Ativo de Germoplasma /UNEB-BA foram submetidas aos tratamentos pré-germinativos: PEG 6000 a-0,6 MPa; PEG 6000 a-1,0 MPa; PEG 6000 a-1,4 MPa e PEG 6000 a -1,8 MPa; $10 \% \mathrm{KNO}_{3} / 24 h ; 20 \% \mathrm{KNO}_{3} / 24 h ; 10 \% \mathrm{KNO}_{3} / 48 \mathrm{~h} ; 20 \% \mathrm{KNO}_{3} / 48 \mathrm{~h} ;$ água/24h; água 148 h e testemunha - sementes não condicionadas, formando um fatorial 10x3+1. Avaliou-se porcentagem de germinação $(G \%)$, tempo médio de germinação $(T M G)$, velocidade de germinação $(V G)$ e índice de velocidade de germinação (IVG). Os dados foram submetidos à análise de variância, seguido de teste de médias (Duncan a 5\%) e regressão. Houve interação entre tratamentos de priming e acesso para todas as características
\end{abstract}


avaliadas, exceto G\%. O PEG 6000 reduziu o TMG (6 a 8 dias) e aumentou a VG e IVG das sementes dos três acessos de araçá nos potenciais de -1,0 a -1,5 MPa. O priming em água promoveu efeito positivo no $T M G$, VG e IVG no acesso $\mathrm{Y} 85$. O $\mathrm{KNO}_{3}$ interferiu de forma negativa na germinação dos três acessos estudados. Dessa forma, foi possível sincronizar a germinação de sementes de araçá dos acessos Y85 e Y97 com PEG 6000 .

Palavras-chave: Caatinga; Araçá; Germinação.

\section{INTRODUCTION}

The Brazilian guava (Psidium guineense Swartz) belongs to the Myrtaceae family and is native to the tropical America, being found from Southern Mexico to Northern Argentina and Brazil (GONZÁLEZ et al., 2005; SANTOS et al., 2014; SOBRAL et al., 2015). This fruit species is widely distributed across several Brazilian biomes, including the Caatinga.

The species is commonly known in Brazil as "araçá verdadeiro", “araçá do campo", or "goiabinha selvagem", among others. It has a great economic potential, both for medicinal use, due to its antimicrobial (GONZÁLEZ et al., 2005; FERNANDES et al., 2012), pharmacological, and antibacterial properties (RODRIGUES et al., 2014), and for direct industrial use, as candy, jam, jelly, or ice cream. It may also be consumed in natura, being appreciated for having high vitamin C contents (SANTOS et al., 2014). The species is also used as a source of resistance against the gall-inducing nematode Meloidogyne enterolobii, which has been decimating guava plantations (Psidium guajava L.), one of the major cultivated fruit species in several regions in Brazil.Such resistance can be used either through the interspecific transfer of resistance genes or through grafting, as $P$. guineense yields a resistant rootstock.

The semiarid region of Bahia state, Brazil, has genetically diverse populations of $P$. guineense, with good, desirable plant and fruit features (SANTOS et al., 2014). However, such diversity is at risk, due to constant deforestation in the areas of natural occurrence of the species.

The Germplasm Active Bank (GAB) of Bahia State University (UNEB), located in Juazeiro municipality, is composed of 103 accessions of $P$. guineense collected during 2010 in six municipalities of the semiarid region of Bahia state. The accessions are stored in cold chamber at $10^{\circ} \mathrm{C}$ and $40 \%$ relative humidity. A total of 37 accessions of the available germplasm had their genetic diversity characterized based on plant and fruit features (SANTOS et al., 2014). The other accessions have not yet been characterized, and many mother plants no longer exist in the wild, having been cut for the implementation of commercial plantations or pastures. Thus, it is increasingly necessary to keep these seeds in good storage conditions in order to avoid loss of genetic diversity. Doing so, it would enable further studies to be performed with the species, particularly approaching its unexplored potentialities.

Santos et al. (2015) studied seed germination of four $P$. guineense accessions from the UNEB GAB and obtained low and uneven germination rates. It remains unknown whether such unevenness is related to conditions and time of storage, or is due to intrinsic features of each accession. Therefore, studies that evaluate the germinability of seeds of these accessions, aiming to obtain a faster and mainly more uniform germination, are necessary, as they would enable future works on the genetic improvement of these accessions. Such works are vital, since the species is not easily propagated vegetatively. So far, propagation of $P$. guineense has only been made via seeds.

Several techniques can accelerate and uniformize seed germination. Seed priming (PEREIRA et al., 2009), for example, consists in the pre-imbibition of seeds in either osmotic solutions or water, aiming at enabling the occurrence of the initial metabolic stages of germination yet without protrusion of the primary root (NASCIMENTO, 2004), i.e., seeds complete stages I and II of imbibition, which are preparatory for germination, without, however, advancing toward stage III, which is characterized by cell elongation and protrusion of the radicle (SANTOS et al., 2008).

Seed priming is promoted by organic osmotic agents, like polyethylene glycol (PEG 6000 or 8000), mannitol, or sucrose; or by inorganic ones, like the salts sodium chloride $(\mathrm{NaCl})$, potassium nitrate $\left(\mathrm{KNO}_{3}\right)$, and magnesium sulfate $\left(\mathrm{MgSO}_{4}\right)$. Because they are osmotically active, $\mathrm{KNO}_{3}$ and $\mathrm{PEG}$ reduce the water 
potential of the solution, enabling a control over the imbibition level and thus contributing to enhance germination and seed vigor (DIAS et al., 2012).

Despite having been initially proposed for the germination of seeds of vegetable species, the seed priming technique has been successfully used in the germination of other crop species, such as Cnidoscolus juercifolius (SILVAet al., 2005), cotton, maize (MURUNGU et al., 2005), sweet maize (OLIVEIRA et al., 2007), Anadenanthera colubrina (REGO et al., 2007), seashore paspalum (SHIM et al., 2008), Stryphnodendron spp.(KISSMANN et al., 2010), sorghum (PATANÈ et al., 2009; OLIVEIRA; GOMES FILHO, 2011), Caesalpinia pyramidalis (ANTUNES et al., 2011), Pinus bungeana (GUO et al., 2012), Cercis siliquastrum (HARONI et al., 2015), and Brazilian guava (MASETTO et al., 2014; SANTOS et al., 2015).

In view of the exposed, we aimed to evaluate the synchronization of the in vitro seed germination of three accessions of the Brazilian guava, using water, PEG 6000, and $\mathrm{KNO}_{3}$ in different times and potentials of osmotic priming.

\section{MATERIALAND METHODS}

The assays were conducted in the Laboratory of Plant Tissue Culture II, in the Institute of Biotechnology Applied to Agriculture (BIOAGRO) of the Federal University of Viçosa (UFV), Viçosa municipality, Minas Gerais state, Brazil, from November 2013 through March 2014.

Seeds of the three $P$. guineense accessions were collected in 2010 at Bahia state, Brazil, in the municipalities of Campo Formoso (accession Y85), Senhor do Bonfim (Y93), and Jacobina (Y97), and stored for four years in cold chamber at $10{ }^{\circ} \mathrm{C}$ and $40 \%$ relative humidity, in the UNEB GAB.

A total 440 seeds of each accession were obtained from the UNEB GAB, disinfected in a laminar flow hood under aseptic conditions by immersion in $70 \%$ ethanol for $1 \mathrm{~min}$. Then, they were immersed into a commercial solution of sodium hypochlorite $(\mathrm{NaOCl})$ with $2 \%$ active chlorine (Super Globo ${ }^{\circledR}$, Rio de Janeiro, Brazil) for 15 minutes, washed thrice in distilled water, and autoclaved. After disinfection, 40 seeds from each accession were allocated to each priming treatment. Treatments were prepared using: PEG 6000 solutions with osmotic potentials adjusted according to Villela et al. (1991), i.e., $-0.6,-1.0,-1.4$, and $-1,8 \mathrm{MPa} ; 10$ and $20 \% \mathrm{KNO}_{3}$ for $24 \mathrm{~h}$; 10 and $20 \% \mathrm{KNO}_{3}$ for $48 \mathrm{~h}$; water for 24 and 48h; and control (non-primed seeds).

The experimental design was completely randomized in a $10 \times 3+1$ factorial scheme (pretreatments $\mathrm{x}$ accessions + control), with four replicates of 10 seeds in each treatment. Data were subjected to analysis of variance and, whenever there was significance, means were compared by Duncan's test at 5\% probability for the qualitative treatments, and a regression analysis was performed to fit the models to the data, using statistical software GENES (CRUZ, 2013).

Seed priming with PEG 6000 was conducted in 250$\mathrm{mL}$ flasks with rigid caps, containing two Germitest ${ }^{\circledR}$ paper disks reduced to the diametric size of the flask bottom, which were humidified with $5 \mathrm{~mL}$ of PEG 6000 solution with the respective osmotic potentials, and autoclaved prior to the onset of the experiment. Treatments were kept in a growth room at $25 \pm 2{ }^{\circ} \mathrm{C}$ for eight days, with a $16-\mathrm{h}$ photoperiod at a $30 \mathrm{imol}$ $\mathrm{m}^{-2} \mathrm{~s}^{-1}$ irradiance, provided by two fluorescent lamps (Luz do Dia Especial, 20 W, Osram, Brazil). This irradiance was quantifiedusing a radiometer $\left(\mathrm{LI}-\mathrm{COR}^{\circledR}, \mathrm{LI}-250 \mathrm{~A}\right.$ Light Meter).

Priming treatments with $\mathrm{KNO}_{3}$ and water were conducted in 125-mL Erlenmeyer flasks containing 15 $\mathrm{mL}$ of the respective solutions, and autoclaved prior to the onset of the experiment. Flasks were sealed with a polyvinyl chloride (PVC) transparent plastic film (Goodyear, São Paulo, Brazil) and kept on an orbital shaker (Tecnal, Piracicaba, Brazil) at $110 \mathrm{rpm}$ in a growth room, at the same above-mentioned conditions.

After proceeding the priming treatments, seeds were washed thrice with distilled water and autoclaved in laminar flow under aseptic conditions. Then they were distributed in $250-\mathrm{mL}$ flasks with rigid caps containing two Germitest ${ }^{\circledR}$ paper disks reduced to the diametric size of the flask bottom, humidified with 5 $\mathrm{mL}$ of distilled water, and autoclaved prior to the onset of the experiment. Flasks were kept in a growth room for 60 days, at the same above-mentioned conditions, until stabilization of germination.

Evaluations were performedalong 60 days, starting at three days after the onset of the experiments. We evaluated the germination percentage; germination speed, calculated by the number of germinated seeds per day (LABOURIAU, 1983); germination speed index,

Revista Árvore, Viçosa-MG, v.40, n.4, p.649-660, 2016 
calculated by the sum of the number of germinated seeds per day, divided by the number of days between sowing and germination (MAGUIRE, 1962); and mean germination time, calculated by counting, on a daily-basis, the germinated seeds, and then using the equation proposed by Labouriau (1983).

\section{RESULTS}

The analysis of variance showed a significant effect on the interaction between priming treatments and accessions for all analyzed variables, except germination percentage (Table 1).

The analysis of variance (Table 2) also revealed that accessions Y85 and Y97 showed better responses for germination percentage, mean germination time, germination speed, and germination speed index when subjected to the priming treatments. These two accessions showed no statistical difference, except for germination speed, which was higher in Y97 seeds. Accession Y93 showed significantly lower means for all analyzed variables, thus responding negatively to the priming treatments.

Regarding priming treatment means (Table 2), there was no statistical difference for germination percentage. Mean germination time differed significantly among treatments, with a higher decrease at treatments with PEG 6000 at all tested osmotic potentials, with a reduction at ca. seven days. The other priming treatments showed a mean germination time equal to or higher than the control. The same behavior was observed for germination speed, which increased at treatments with PEG 6000 and decreased at the other treatments.

Treatments with PEG 6000 and water for $24 \mathrm{~h}$ imbibition did not differ from the control, thus not

Table 1 - Summary of the analysis of variance for variables: germination percentage $(G)$, mean germination time (MGT), germination speed (GS), and germination speed index (GSI), evaluated in the synchronization of seed germination of three Psidium guineense Swartz accessions (A) subjected to different priming treatments $(P)$.

Tabela 1 - Resumo da análise de variância para as variáveis: porcentagem de germinação $(G)$, tempo médio de germinação $(T M G)$, velocidade de germinação $(V G)$ e indice de velocidade de germinação (IVG) na sincronização da germinação de sementes obtido da avaliação de três acessos de araçá (A), sob diferentes condicionamentos (Priming-P).

\begin{tabular}{|c|c|c|c|c|c|}
\hline \multirow[t]{2}{*}{ Source of variation } & \multicolumn{5}{|c|}{ Mean squares } \\
\hline & DF & $\mathrm{G}$ & MGT & GS & GSI \\
\hline Acessions (A) & 2 & $14339.39 * *$ & $7271.26 * *$ & $0.0121 * *$ & $1.397 * *$ \\
\hline Priming treatments $(\mathrm{P})$ & 10 & $840.61 *$ & $375.25 * *$ & $0.0010 * *$ & $0.099 * *$ \\
\hline $\mathrm{A} \times \mathrm{P}$ & 20 & $463.56^{\mathrm{ns}}$ & $181.95 * *$ & $0.0003 * *$ & $0.044 * *$ \\
\hline $\mathrm{A} / \mathrm{P}$ & 22 & - & $826.43 * *$ & $0.0014 * *$ & $0.167 * *$ \\
\hline $\mathrm{A} / \mathrm{P}-0$ & 2 & - & $211.39 * *$ & $0.0005 * *$ & $0.066 * *$ \\
\hline A/P --0.6 MPa PEG 6000 & 2 & - & $176.55 * *$ & $0.0015 * *$ & $0.294 * *$ \\
\hline $\mathrm{A} / \mathrm{P}--1.0 \mathrm{MPa}$ PEG 6000 & 2 & - & $227.2 * *$ & $0.0018 * *$ & $0.281 * *$ \\
\hline $\mathrm{A} / \mathrm{P}--1.4 \mathrm{MPa}$ PEG 6000 & 2 & - & $187.39 * *$ & $0.0014 * *$ & $0.256 * *$ \\
\hline $\mathrm{A} / \mathrm{P}--1.8 \mathrm{MPa}$ PEG 6000 & 2 & - & $261.27 * *$ & $0.003 * *$ & $0.178 * *$ \\
\hline $\mathrm{A} / \mathrm{P}-\mathrm{H}_{2} \mathrm{O} / 24 \mathrm{~h}$ & 2 & - & $1351.6 * *$ & $0.0015 * *$ & $0.214 * *$ \\
\hline $\mathrm{A} / \mathrm{P}-10 \% \mathrm{KNO}_{3} / 24 \mathrm{~h}$ & 2 & - & $1102.5 * *$ & $0.0011 * *$ & $0.115 * *$ \\
\hline $\mathrm{A} / \mathrm{P}-20 \% \mathrm{KNO}_{3} / 24 \mathrm{~h}$ & 2 & - & $1260.16 * *$ & $0.001 * *$ & $0.131 * *$ \\
\hline $\mathrm{A} / \mathrm{P}-\mathrm{H}_{2} \mathrm{O} / 48 \mathrm{~h}$ & 2 & - & $1168.57 * *$ & $0.0012 * *$ & $0.098 * *$ \\
\hline $\mathrm{A} / \mathrm{P}-10 \% \mathrm{KNO}_{3} / 48 \mathrm{~h}$ & 2 & - & $1474.63 * *$ & $0.0011 * *$ & $0.111 * *$ \\
\hline $\mathrm{A} / \mathrm{P}-20 \% \mathrm{KNO}_{3} / 48 \mathrm{~h}$ & 2 & - & $1669.45 * *$ & $0.0009 * *$ & $0.097 * *$ \\
\hline $\mathrm{P} / \mathrm{A}$ & 30 & - & $246.38 * *$ & $0.0005 * *$ & $0.063 * *$ \\
\hline $\mathrm{P} / \mathrm{Y} 85$ & 10 & - & $19.29^{\mathrm{ns}}$ & $0.0001 *$ & $0.02 *$ \\
\hline P/Y93 & 10 & - & $650.74 * *$ & $0.0003 * *$ & $0.025 *$ \\
\hline P/Y 97 & 10 & - & $69.11 * *$ & $0.001 * *$ & $0.142 * *$ \\
\hline Residue & 99 & - & 11.14 & 0.00004 & $0.009 * *$ \\
\hline Total & 131 & & & & \\
\hline Mean & 70.378 & & 27.19 & 4.43 & 0.347 \\
\hline CV (\%) & & 26.76 & 12.28 & 14.52 & 27.18 \\
\hline
\end{tabular}

${ }^{\mathrm{ns}}$ Non-significantat $5 \%$ probability by the F-test. * and ** Significantat 5 and $1 \%$ probability, respectively, by the F-test.

${ }^{n}$ Não significativo ao nivel de $5 \%$ probabilidade de erro pelo teste $F$. $* e^{* *}$ Significativo ao nivel de 5 e $1 \%$ de probabilidade de erro respectivamente, pelo teste $F$. 
Table 2 - Means for variables: germination percentage (G), mean germination time (MGT), germination speed (GS), and germination speed index (GSI), evaluated in the synchronization of seed germination of three Psidium guineense Swartz accessions subjected to different priming treatments.

Tabela 2 - Médias dos três acessos de araçá (Psidium guineense Swartz) e dos tratamentos de priming para as variáveis: porcentagem de germinação $(G)$, tempo médio de germinação $(T M G)$, velocidade de germinação $(V G)$ e indice de velocidade de germinação (IVG) na sincronização da germinação de suas sementes.

\begin{tabular}{|c|c|c|c|c|}
\hline \multirow[t]{2}{*}{ Accession } & \multicolumn{4}{|c|}{ Variables } \\
\hline & G & MGT & GS & GSI \\
\hline Y85 & $83.41^{\mathrm{a}}$ & $21.5^{\mathrm{a}}$ & $0.047^{\mathrm{b}}$ & $0.41^{\mathrm{a}}$ \\
\hline Y93 & $49.77^{b}$ & $41.90^{\mathrm{b}}$ & $0.027^{\mathrm{c}}$ & $0.147^{b}$ \\
\hline Y97 & $77.95^{\mathrm{a}}$ & $18.55^{\mathrm{a}}$ & $0.059^{\mathrm{a}}$ & $0.49^{\mathrm{a}}$ \\
\hline \multirow[t]{2}{*}{ Priming treatment } & \multicolumn{4}{|c|}{ Variables } \\
\hline & G & MGT & GS & GSI \\
\hline Control & $81.67^{\mathrm{a}}$ & $27.02^{b}$ & $0.039^{\mathrm{c}}$ & $0.334^{\mathrm{abcd}}$ \\
\hline$-0.6 \mathrm{MPa}$ PEG 6000 & $80.0^{\mathrm{a}}$ & $20.46^{\mathrm{a}}$ & $0.053^{\mathrm{ab}}$ & $0.474^{\mathrm{ab}}$ \\
\hline -1.0 MPa PEG 6000 & $83.33^{\mathrm{a}}$ & $20.92^{\mathrm{a}}$ & $0.053^{\mathrm{ab}}$ & $0.492^{\mathrm{a}}$ \\
\hline -1.4 MPa PEG 6000 & $75.83^{\mathrm{a}}$ & $20.64^{\mathrm{a}}$ & $0.053^{\mathrm{ab}}$ & $0.443^{\mathrm{abc}}$ \\
\hline -1.8 MPa PEG 6000 & $70.0^{\mathrm{a}}$ & $20.37^{\mathrm{a}}$ & $0.057^{\mathrm{a}}$ & $0.410^{\mathrm{abcd}}$ \\
\hline $\mathrm{H}_{2} \mathrm{O} / 24 \mathrm{~h}$ & $65.0^{\mathrm{a}}$ & $29.58^{\mathrm{bc}}$ & $0.042^{\mathrm{bc}}$ & $0.317^{\mathrm{abcd}}$ \\
\hline $10 \% \mathrm{KNO}_{3} / 24 \mathrm{~h}$ & $65.0^{\mathrm{a}}$ & $30.36^{\mathrm{bcd}}$ & $0.040^{\mathrm{c}}$ & $0.286^{\mathrm{bcd}}$ \\
\hline $20 \% \mathrm{KNO}_{3} / 24 \mathrm{~h}$ & $63.33^{\mathrm{a}}$ & $31.86^{\mathrm{bcd}}$ & $0.037^{\mathrm{c}}$ & $0.276^{\mathrm{bcd}}$ \\
\hline $\mathrm{H}_{2} \mathrm{O} / 48 \mathrm{~h}$ & $65.83^{\mathrm{a}}$ & $30.04^{\mathrm{bcd}}$ & $0.41^{\mathrm{bc}}$ & $0.289^{\mathrm{bcd}}$ \\
\hline $10 \% \mathrm{KNO}_{3} / 48 \mathrm{~h}$ & $65.0^{\mathrm{a}}$ & $32.66^{\mathrm{cd}}$ & $0.037^{\mathrm{c}}$ & $0.269^{\mathrm{cd}}$ \\
\hline $20 \% \mathrm{KNO}_{3} / 48 \mathrm{~h}$ & $59.17^{\mathrm{a}}$ & $35.13^{\mathrm{d}}$ & $0.034^{c}$ & $0.234^{\mathrm{d}}$ \\
\hline
\end{tabular}

Means followed by the same letter do not differ by Duncan's test at $5 \%$ probability.

Médias seguidas pela mesma letra não diferem entre si pelo teste de Duncan a $5 \%$ de probabilidade.

promoting any increase in the germination speed index. This parameter, however, decreased at treatments with $\mathrm{KNO}_{3}$ and water for $48 \mathrm{~h}$ imbibition (Table 2).

The mean germination time (Figure 1A), germination speed (Figure 1B), and germination speed index (Figure 1C) values fit the squared model of regression for all three accessions.

PEG6000 treatments decreased the mean germination time of seeds from all accessions. Accession Y97 showed reduced values of this parameter in the control treatment (19.96 days), followed by Y85 (26.62) and Y93 (34.48). When subjected to the priming treatments, the accessions showed a reduction in mean germination time of six to eight days. This parameter decreased with increasing water stress (i.e., more negative osmotic potentials), showing the point of maximum decreaseat $-1.5 \mathrm{MPa}$ for accession Y97 (12.32 days) and -1.2 MPa for Y85 and Y93, and decreasing to 20.30 and 26.80 , respectively (Figure 1A).

Seeds of all three accessions showed increased values of germination speed. Accession Y97 showed the highest values in relation to Y85 and Y93. In Y97, the maximum value was observed at $-1.0 \mathrm{MPa}$, decreasing from-1.2 MPa. In Y85, the maximum increase was observed at $-1.0 \mathrm{MPa}$, being higher than Y93, in which the maximum increase occurred at -1.2 $\mathrm{MPa}$ (Figure 1B).

Accession Y97 also showed the highest values for germination speed index, with a maximum increase of 0.775 day at $-1.0 \mathrm{MPa}$, and decreasing values at increasingly negative potentials. The same tendency was observedin Y85, yet with a lower increase, and maximum decrease at $-1.8 \mathrm{MPa}$. The lowest increase was observed in Y93 seeds, with maximum increase at $-1.2 \mathrm{MPa}$ (Figure 1C).

Data on mean germination time, germination speed, and germination speed index from all three accessions fit the squared model of regression on treatments with $\mathrm{KNO}_{3}$ for $24 \mathrm{~h}$ imbibition (Figure 2).

There was variation among accessions in the responses to treatments 0,10 , and $20 \% \mathrm{KNO}_{3}$. Accession Y 85 showed the highest mean germination time at $0 \%$ $\mathrm{KNO}_{3}$ (water for $24 \mathrm{~h}$ imbibition). Accessions Y97 and Y85 showed similar behavior, but the former showed a maximum decrease (19.86 days) at ca. $8 \% \mathrm{KNO}_{3}$. The same performance was observed in Y93, with no significant decrease; it should be noted that seeds

Revista Árvore, Viçosa-MG, v.40, n.4, p.649-660, 2016 

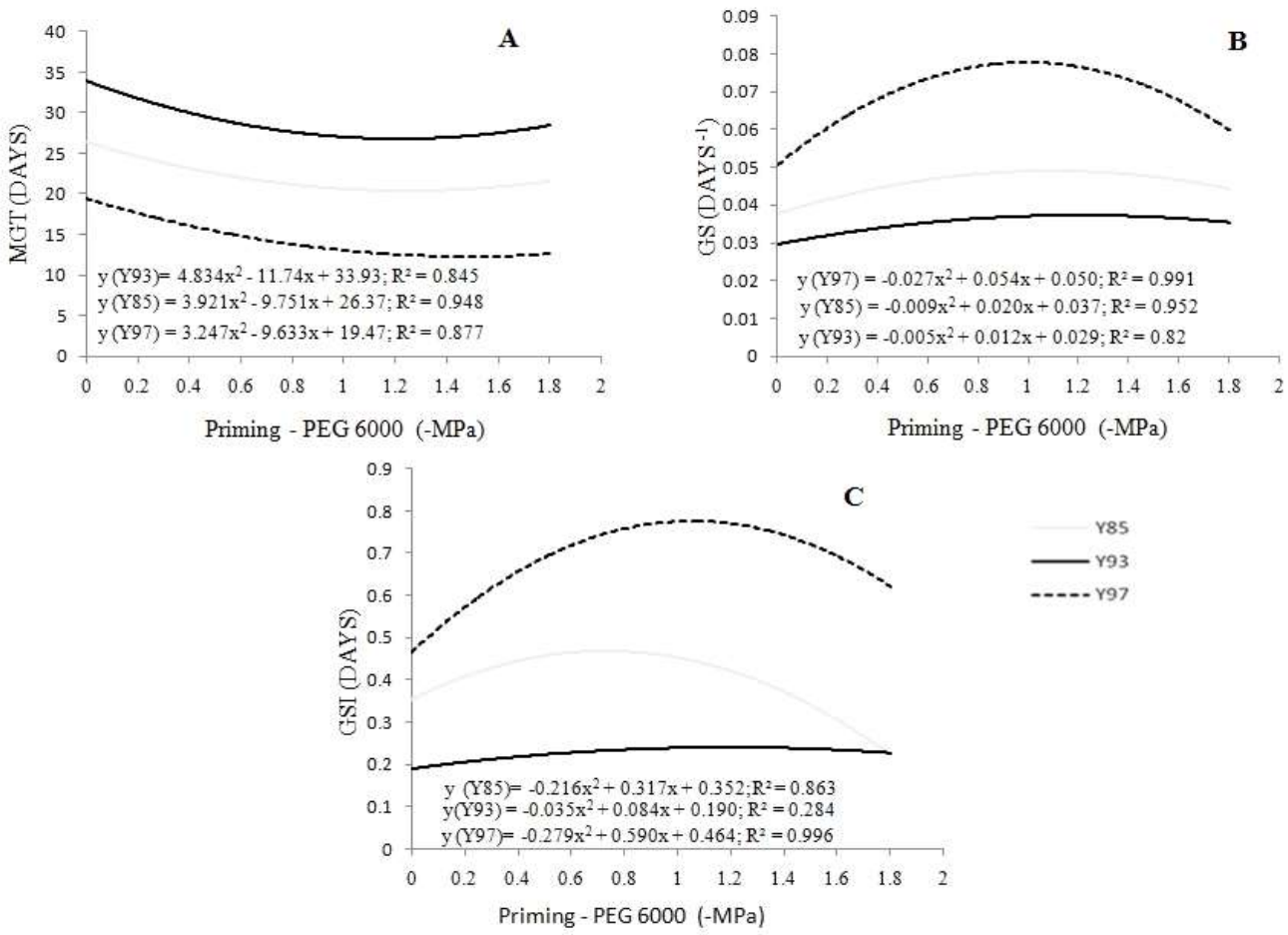

Figure 1 - Mean germination time (MGT) (A), germination speed (GS) (B), and germination speed index (GSI) (C) evaluated in the synchronization of seed germination of three Psidium guineense Swartz accessions subjected to different PEG 6000 treatments $(-0.6,-1.0,-1.4$, and $-1.8 \mathrm{MPa})$.

Figura 1 - Tempo médio de germinação $(A)$, velocidade de germinação $(B)$ e índice de velocidade de germinação $(C)$ na sincronização da germinação de três acessos de araçá (Psidium guineense Swartz) submetidos a diferentes tratamentos de PEG 6000 (-0,6; -1,0; -1,4; -1,8 MPa).

from this accession took over 50 days to germinate at $0 \% \mathrm{KNO}_{3}$ for $24 \mathrm{~h}$ imbibition (Figure $2 \mathrm{~A}$ ).

Treatments with 10 and $20 \% \mathrm{KNO}_{3}$ significantly decreased the germination speed of accession Y 85 seeds (Figure 2B). Accession Y97, on the other hand, showed increased values of this trait, with a maximum increase at $10 \% \mathrm{KNO}_{3}$. As for accession $\mathrm{Y} 93, \mathrm{KNO}_{3}$ treatments caused no increase in germination speed. The same tendency was observed for the germination speed index (Figure 2C).

When subjected to the priming treatments with $\mathrm{KNO}_{3}(0,10$, and $20 \%)$ for $48 \mathrm{~h}$, seeds showed a similar performance to the one observed after $24 \mathrm{~h}$ imbibition, with no increase in mean germination time (Figure 3A), germination speed (Figure 3B), or germination speed index (Figure $3 \mathrm{C}$ ) at treatments with 10 or $20 \% \mathrm{KNO}_{3}$. The water-priming treatment for $48 \mathrm{~h}$ imbibition therefore yield better results.

\section{DISCUSSION}

Priming influenced the germination of $P$. guineense seeds both negatively and positively, depending on the accession, priming type, and priming potential. There was, therefore, an interdependency between the accessions and priming treatments for the evaluated traits. This performance has also been observed in other works, for accessions of $P$. guineense (SANTOS et al., 2015) and varieties of Solanum sessiliflorum (PEREIRA et al., 2012) and Stryphnodendron spp. (KISSMANN et al., 2010). All these studies corroborate the findings of Nascimento (2004), who attributes these variable effects of seed priming to variations among species, cultivars, and even seed lots of a same species. According to Pereira et al. (2008), the success of priming depends on several factors, such as the initial quality of seeds, the osmotic potential of the solution, and the osmotic agent used. Genetic factors intrinsic to the accessions may also affect seed priming. 

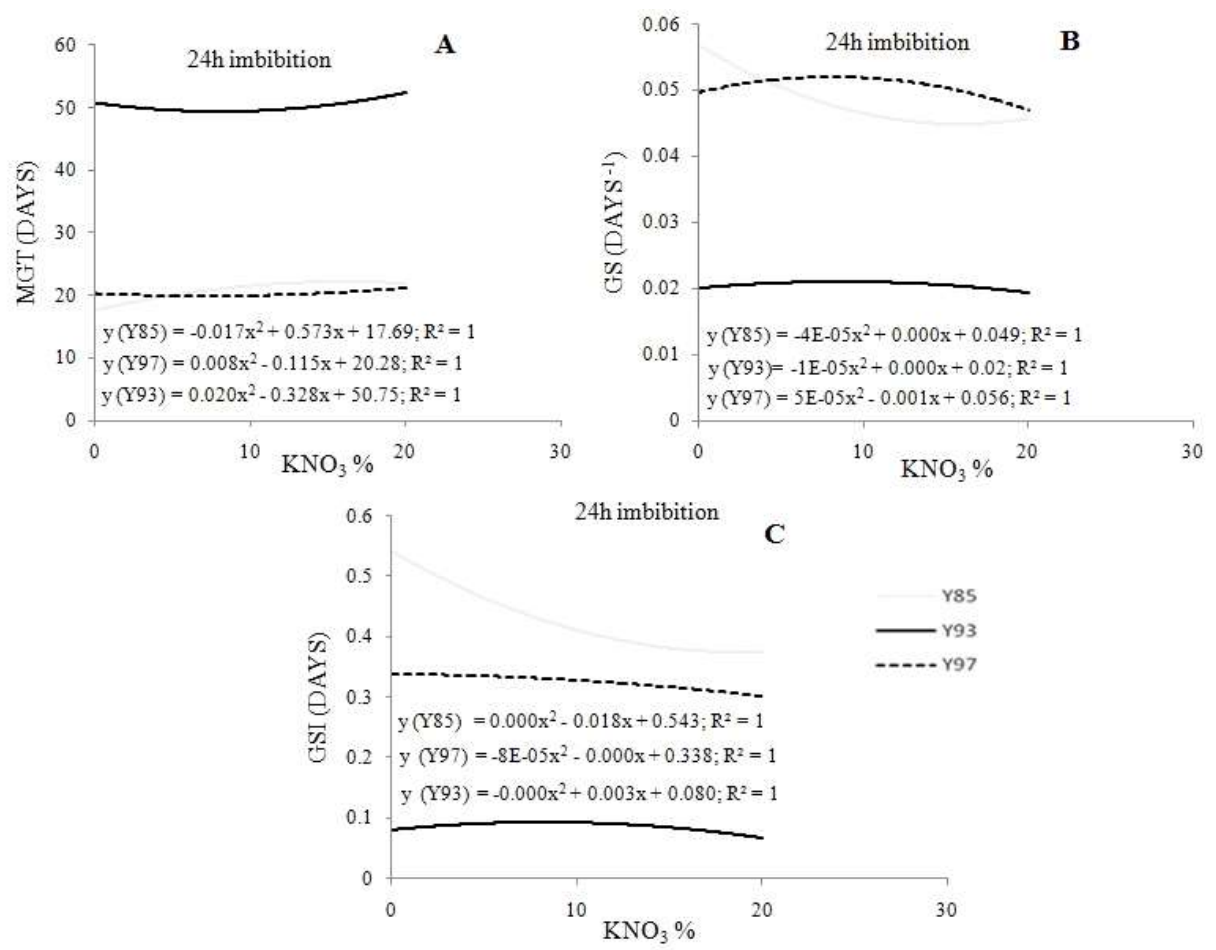

Figure 2 - Mean germination time (MGT) (A), germination speed (GS) (B), and germination speed index (GSI) (C) evaluatedin the synchronization of seed germination of three Psidium guineense Swartz accessions subjected to different $\mathrm{KNO}_{3}$ treatments $(0,10$, and $20 \%)$ for 24 hours imbibition.

Figura 2 - Tempo médio de germinação $(A)$, velocidade de germinação $(B)$ e índice de velocidade de germinação $(C)$ na sincronização da germinação de três acessos de araçá (Psidium guineense Swartz) submetidos a diferentes tratamentos de $\mathrm{KNO}_{3}(0,10$ e $20 \%)$ por $24 \mathrm{~h}$ de embebição.

Accessions Y85 and Y97 showed a good germinability in the control treatment, which may be related to the initial vigor of seeds or to their intrinsic genetic factors, as stated. Seeds showed high viability and vigor even after four years of storage at the UNEB GAB, which shows that the storage conditions of this germplasm bank are adequate for the conservation of seeds of these $P$. guineense accessions. This factor may well have interfered with the germination percentages obtained for the evaluated accessions. However, even showing good vigor, both accessions responded positively to treatments -1.0 to $-1.5 \mathrm{MPa}$ PEG 6000 . The data corroborate those of Santos et al. (2015), who obtained similar results for accession Y 85 treated with -1.0 MPa PEG 6000 after one year storage at the UNEB GAB. Positive results with PEG 6000 have also been observed in works with other Caatinga plant species, such as Anadenanthera colubrina (REGO et al., 2007), Cnidoscolus juercifolius (SILVA et al., 2005), and
Caesalpinia pyramidalis (ANTUNES et al., 2011), with the maximum and minimum potentials varying depending on the species and genotype (accession).

When comparing germination between accession Y85 seeds stored in the UNEB GAB for one year (SANTOS et al., 2015) and those stored for four years, we observed that the latter conditions maintain seed vigor and viability, as the $P$. guineense seeds showed similar performance after both storage times.

The mean germination time we observed in seeds from accessions Y85 and Y97, as well as in non-primed seeds from accession Y93, were similar to those obtained by Santos et al. (2015) for accessions Y95 and Y85. They were higher, however, than the ones observed by Masetto et al. (2014), who reported a minimum value of 21 days with -0.87 MPa PEG 6000. In non-primed seeds, Masetto et al. (2014) observed the beginning of germination at 35 days after sowing, with a mean

Revista Árvore, Viçosa-MG, v.40, n.4, p.649-660, 2016 

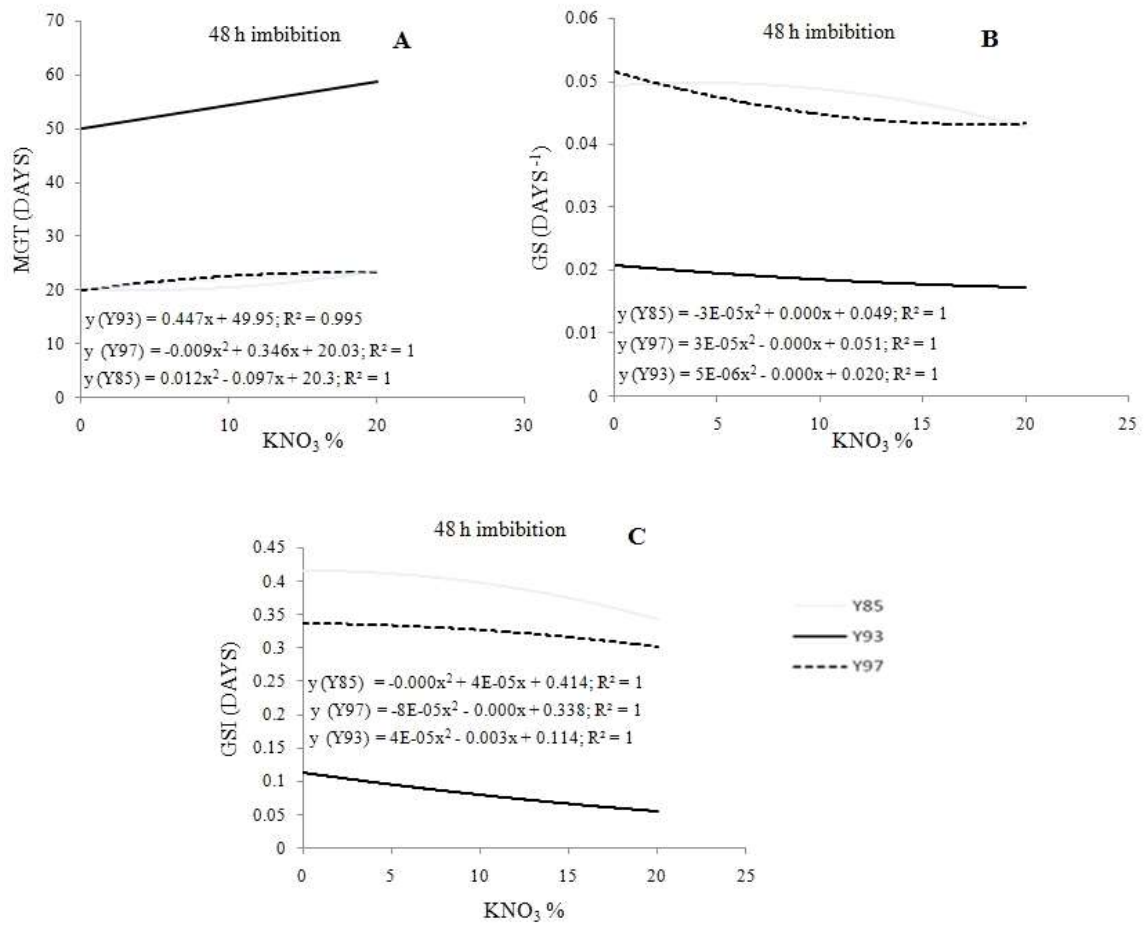

Figure 3 - Mean germination time (MGT) (A), germination speed (GS) (B), and germination speed index (GSI) (C) evaluated in the synchronization of seed germination of three Psidium guineense Swartz accessions subjected to different $\mathrm{KNO}_{3}$ treatments $(0,10$, and $20 \%)$ for 48 hours imbibition.

Figura 3 - Tempo médio de germinação $(A)$,velocidade de germinação $(B)$ e índice de velocidade de germinação $(C)$ na sincronização da germinação de três acessos de araçá (Psidium guineense Swartz) submetidos a diferentes tratamentos de $\mathrm{KNO}_{3}(0,10$ e 20\%) por $48 \mathrm{~h}$ de embebição.

germination time of 47 days. The variations observed by both us and Masetto et al. (2014), as well as the one observed by Santos et al. (2015), may be related to storage conditions, local environmental factors at each site of origin of the seeds, or even to the genetic variability within $P$. guineense, a species whose area of natural occurrence extends throughout several Brazilian biomes.

Germination speed and germination speed index varied widely not only among treatments but also among accessions. These traits significantly increased in response to PEG 6000 at potentials -1.0 to $-1.5 \mathrm{MPa}$. The highest values were observed in accession Y97 seeds, which showed their highest vigor in relation to the other accessions, followed by Y85 and Y93. According to Carvalho e Nakagawa (1999), seeds with higher germination speed indexes are more vigorous. Thus, our results corroborate those obtained by Santos et al. (2015) for the same species, and partially corroborate those observed with other species, such as Stryphnodendron spp. (KISSMANN et al., 2010), Solanum sessiliflorum (PEREIRA et al., 2012), and Myracrodruon urundeuva (VIRGENS et al., 2012), in all of which the priming with PEG 6000 acted negatively on the increase in germination percentage, germination speed, and germination speed index. Such behavior was only observed in accession Y93 seeds; in the other two accessions, priming influenced these parameters positively.

According to Marcos Filho (2005), in order for osmotic priming to be successful, it is required that the evaluated seeds have low germinability and vigor, as the lowest is the quality of seeds, the more positive will be the effects caused by the treatment. However, even though accession Y93 seeds showed low germinability in the control treatment compared to accessions Y85 and Y97, seed priming did not positively affected the germination synchronization. This could be related to either genetic features intrinsic to this accession or to seed dormancy. 
Santos et al. (2015) obtained the imbibition curve of accession Y85 seeds and observed no dormancy, as seeds completed stage III of germination, which can only be achieved by non-dormant seeds (BEWLEY et al., 2013). Yet, this condition may vary among accessions.

The use of $\mathrm{KNO}_{3}$ is recommended in the rules for seed analysis (BRASIL, 2009) as an auxiliary treatment to overcome dormancy in seeds of several species. This priming agent acts by stimulating germination, as it activates the pentose phosphate pathway, providing additional oxygen to the germination process (MARCOS FILHO, 2005). $\mathrm{KNO}_{3}$ has been successfully used on the seed germination of several crop species, like eggplant (NASCIMENTO et al., 2008), seashore paspalum (SHIM et al., 2008), tomato (NAWAZ et al., 2011), Solanum sessiliflorum (PEREIRA et al., 2012), Pinus bungeana (GUO et al., 2012), Abelmoschus esculentus (SHARMA et al., 2014), and Cercis siliquastrum (HARONI et al., 2015), among others. However, due to its low molecular weight, $\mathrm{KNO}_{3}$ can penetrate seed tissues and thereby cause phytotoxicity, which is usually more severe with increasing time of seed exposure to the solution (BONOME et al., 2006) and increasing concentrations of the salt. This might have been the case of what happened to the three accessions studied herein, whose seeds had the germination affected negatively by $\mathrm{KNO}_{3}$.

The above-mentioned works that were successful on obtaining germination of $\mathrm{KNO}_{3}$-primed seeds have used either the same imbibition time we used herein, or lower/higher times but with lower concentrations or complementary treatments (GUO et al., 2012; HARONI et al., 2015). In such works, the concentration used depended on the studied species. Nawaz et al. (2011) obtained significantly increased germination percentages and germination speeds, and significantly decreased mean germination times in seeds of two varieties of tomato subjected to $25 \mathrm{mM}(0.25 \%) \mathrm{KNO}_{3}$ with $24 \mathrm{~h}$ imbibition. Haroni et al. (2015), on the other hand, obtained higher germination features in seeds of Cercis siliquastrum at $750 \mathrm{mM}(7 \%) \mathrm{KNO}_{3}$ after $48 \mathrm{~h}$ imbibition, but with a previous $24 \mathrm{~h}$ imbibition at $100^{\circ} \mathrm{C}$. Thus, we recommend future works to test lower $\mathrm{KNO}_{3}$ concentrations and/or combinations with other treatments in order to further evaluate the success of seed priming in P. guineense.

Water is one of the most important agents for germination, as it reactivates seed metabolism and is involved either directly or indirectly in all further germination steps (REGO et al., 2007). In our work, we observed positive results for germination only in accession Y85 seeds when subjected to $0 \% \mathrm{KNO}_{3}$ for $24 \mathrm{~h}$ imbibition. Scalon et al. (2014), working with seeds of Stryphnodendron spp., showed that water-priming can be either more effective or similar to osmotic priming in enhancing germination under stressing conditions. The same tendency was observed by Sharma et al. (2014), who obtained either equal or higher germination percentage, mean germination time, and germination speed index in okra seeds after priming with $2 \% \mathrm{KNO}_{3}$.

\section{CONCLUSIONS}

- We could synchronize seed germination of accessions Y85 and Y97 of $P$. guineense using PEG 6000 at osmotic potentials -1.0 to $-1.5 \mathrm{MPa}$;

. Water-priming for a 24-h imbibition period was efficient in synchronizing germination only of accession Y85 seeds;

. Priming with 10 and $20 \% \mathrm{KNO}_{3}$ is not indicated for synchronizing germination of $P$. guineense seeds from the UNEB GAB.

\section{ACKNOWLEDGMENTS}

The authors would like to thank Conselho Nacional de Desenvolvimento Científico e Tecnológico (CNPq) (Brazil), Coordenação de Aperfeiçoamento de Pessoal de Nível Superior (CAPES) (Brazil), Fundação de Amparo à Pesquisa do Estado de Minas Gerais (FAPEMIG) (Belo Horizonte, MG, Brazil), and Universidade do Estado da Bahia (UNEB) (Juazeiro, BA, Brazil) for financial support.

\section{REFERENCES}

ANTUNES, C.G.C.; PELACANI, C.R.; RIBEIRO, R.C.; SOUZA, J.V.; SOUZA, C.L.M.; CASTRO, R.D. Germinação de sementes de Caesalpinia pyramidalis tul. (catingueira) submetidas a deficiência hídrica. Revista Árvore, v.35, n.5, p.1007-1015, 2011.

BEWLEY, J.D.; BRADFORD, K.J.; HILHORST, H.W.M.; NONOGAKI, H. Seeds: physiology of development germination and dormancy. New York: Springer, 2013.392p.

BRASIL. Ministério da Agricultura e Reforma Agrária. Regras para análise de

Revista Árvore, Viçosa-MG, v.40, n.4, p.649-660, 2016

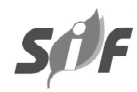


sementes. Brasília: SNAD/DNDV/CLAV, 2009. 398p.

BONOME, L.T.S.; GUIMARÃES, R.M.; OLIVEIRA, J.A.; ANDRADE, V.C.; CABRAL, P.S. Efeito do condicionamento osmótico em sementes de Brachiaria brizantha cv. Marandu. Ciência e Agrotecnologia, v.30, n.3, p.422428, 2006.

CARVAlho, N.M.; NAKAGAWA, J. Sementes: ciência, tecnologia e produção. 4.ed. Jaboticabal: FUNEP, 2000. 588p.

CRUZ, C.D. GENES - A software package for analysis in experimental statistics and quantitative genetics. Acta Scientiarum Agronomy, v.35, p.271-276, 2013.

DIAS, M.A.; SOUZA NETO, J.D.; CONCEIÇÃO, P.M.; TOREZANI, S.C. Resposta fisiológica de sementes de mamão submetidas ao condicionamento osmótico. Revista Caatinga, v.25, n.4, p.82-87, 2012.

FERNANDES, T.G.; MESQUITA, A.R.C.; RANDAU, K.P.; FRANCHITTI, A.A.; XIMENES, E.A. In vitro synergistic effect of Psidium guineense (Swartz) in combination with antimicrobial agents against Methicillin-Resistant Staphylococcus aureus Strains. The Scientific World Journal, 2012(2012), Article ID 158237, 7p.

GONZÁLEZ, A.M.N.; GONZÁLEZ, M.B.R.; PINTO, N.L.S. Estudio fitoquímico e actividad antibacterial de Psidium guineense Sw (choba) frente a Streptococcus mutans, agente causal de caries dentales. Revista Cubana de Plantas Medicinais, v.1, n.10, p.3-4, 2005.

GUO S.; WANG, Y.; WANG, W. Effects of priming treatments on germination and biochemical characteristics of Pinus bungeana seeds.

Forestry Studies in China, v. 14, n.3, p.200-204, 2012.

HARONI, N.N.; TABARI, M.; DEY, D. Effect of halopriming treatment on seed germination and seedling emergence of Judas tree (Cercis siliquastrum L., Caesalpiniaceae) from Zanjan, Iran. African Journal of Agricultural Research, v.10, n.23, p.2355-2362, 2015.

Revista Árvore, Viçosa-MG, v.40, n.4, p.649-660, 2016
KISSMANN, C.; SCALON, S.D.P.Q.; MOTA, L.H.D.S.; VIEIRA, M.D.C. Germinação de sementes de Stryphnodendron Mart. osmocondicionadas.

Revista Brasileira de Sementes, v.32, n.2, p.26-35, 2010.

LABOURIAU, L.G. A germinação das sementes. Washington: Secretaria da OEA, 1983. $173 p$.

MAGUIRE, J.D. Speed of germination-and in selection and evaluation for seeding emergence and vigor. Crop Science, v.2, n.2, p.176-177, 1962.

MARCOS FILHO, J. Fisiologia de sementes de plantas cultivadas. Piracicaba: FEALQ, 2005. 495p.

MASETTO, T.E.; NEVES, E.M.S.; SCALON, S.D.P.Q.; DRESCH, D.M. Drying, storage and osmotic conditioning of Psidium guineense Swartz Seeds. American Journal of Plant Sciences, n.5, p.2591-2598, 2014.

MURUNGU, F.S.; NYAMUGAFATA, P.; CHIDUZA, C.; CLARK, L.J.; WHALLEY, W.R. Effects of seed priming and water potential on germination of cotton (Gossypium hirsutum L.) and maize (Zea mays L.) in laboratory assays. South African Journal of Plant and Soil, v.2, n.1, p.64-70, 2005.

NAKAGAWA, J. Testes de vigor baseados no desempenho das plântulas. In: KRZYZANOWSKI, F.C.; VIEIRA, R.D.; FRANÇA NETO, J.B. (Ed.). Vigor de sementes: conceitos e testes. Londrina: ABRATES, 1999. p.2-1-2-24.

NASCIMENTO, W.M.; LIMA, L.B. Condicionamento osmótico de sementes de berinjela visando a germinação sob temperaturas baixas. Revista Brasileira de Sementes, v.30, n.2, p.224-227, 2008.

NASCIMENTO, W.M. Condicionamento osmótico de sementes de hortaliças. Brasília: Embrapa Hortaliças, 2004. 12 p. (Circular Técnica, 33).

NAWAZ, A.; AMJAD, M.; PERVEZ, M.A.; AFZAL, I. Effect of halopriming on germination and seedling vigour of tomato. African 
Journal of Agricultural Research, v.6, n.15, p.3551-3559, 2011.

OLIVEIRA, A.B.; GOMES FILHO, E.

Estabelecimento de plântulas de sorgo oriundas de sementes osmocondicionadas de diferentes qualidades fisiológicas. Revista Brasileira de Ciências Agrárias, v.6, n.2, p.223-229, 2011.

OLIVEIRA, A.S.; SILVA-MANN, R.; SANTOS, M.F.; GOIS, I.B.; BARRETTO, M.C.V.

Condicionamento osmótico em sementes de milho doce submetidas ao armazenamento. Revista Ciência Agronômica, v.38, n.4, p.444-448, 2007.

PATANÈ, C.; CAVALLARO, V.; COSENTINO, S.L. Germination and radicle growth in unprimed and primed seeds of sweet sorghum as affected by reduced water potential in $\mathrm{NaCl}$ at different temperatures. Industrial Crops and Products, v.30, n.1, p.1-8, 2009.

PEREIRA, M.D.; SOARES, E.R.; LOPES, J.C.; LIMA, E.E. Condicionamento osmótico de sementes de cubiu. Revista Caatinga, v.25, n.3, p.12-17, 2012 .

PEREIRA, M.D.; DIAS, D.C.F.D.S.; DIAS, L.A.D.S.; ARAÚJO, E.F. Primed carrot seeds performance under water and temperature stress. Scientia Agricola, v.66, n.2, p.174-179, 2009.

PEREIRA, M.D.; DIAS, D.C.F.D.S.; DIAS, L.A.D.S.; ARAUUJO, E.F. Germination and vigor of carrot seeds primed in moistened paper and aerated solution. Revista Brasileira de Sementes, v.30, n.2, p.137-145, 2008.

REGO, S.S.; FERREIRA, M.M.; NOGUEIRA, A.C.; GROSSI, F. Influência de potenciais osmóticos na germinação de sementes de Anadenanthera colubrina (Veloso) Brenan (Angico-branco) Mimosaceae. Revista Brasileira de Biociências, v.5, supl. 2, p.549-551, 2007.

RODRIGUES, C.G.; FERREIRA, P.R.B.; MENDES, C.S.O.; JUNIOR, R.R.; VALERIO, H.M.; BRANDI, I.V.; OLIVEIRA, D.A. Antibacterial activity of tannins from Psidium guineense Sw. (Myrtaceae). Journal of Medicinal Plants Research, v.8, n.35, p.1095-1100, 2014.

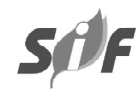

SANTOS, M.A.C.; QUEIROZ, M.A.; BISPO, J.D.S.; DANTAS, B.F. Seed germination of Brazilian guava (Psidium guineense Swartz.). Journal of Seed Science, v.37, n.4, p.214-221, 2015.

SANTOS, M.A.C.; QUEIROZ, M.A.; SANTOS, A.S.; SANTOS, L.C.; CARNEIRO, P.C.S.

Diversidade genética entre acessos de araçá de diferentes municípios do semiárido baiano.

Revista Caatinga, v.27, n.2, p.48-57, 2014.

SANTOS, M.C.A.; AROUCHA, E.M.M.; SOUZA, M.S.; SILVA, R.F.; SOUSA, P.A. Condicionamento osmótico de sementes - Revisão de literatura. Revista Caatinga, v.21, n.2, p.1-6, 2008.

SCALON, S.P.Q.; MASETTO, T.E.; MATOS, D.S.C.; MOTTA, L. Condicionamento fisiológico e níveis de sombreamento em sementes de barbatimão (Stryphnodendron polyphyllum (Mart.) e $S$. adstringens (Mart.) Coville). Revista Árvore, v.38, n.1, p.145-153, 2014.

SHARMA, A.D.; RATHORE, S.V.S.; SRINIVASAN, K.; TYAGI, R.K. Comparison of various seed priming methods for seed germination, seedling vigour and fruit yield in okra (Abelmoschus esculentus L. Moench). Scientia

Horticulturae, v. 165, p.75-81, 2014.

SHIM, S.I.; MOON, J.C.; JANG, C.S.; RAYMER, P.; KIM, W. Effect of Potassium Nitrate Primingon Seed Germination of Seashore Paspalum. HortScience, v.43, n.7, p.2259-2262, 2008.

SILVA, L.M.; AGUIAR, I.B.; MORAIS, D.L. VIÉGAS, R.A. Estresse hídrico e condicionamento osmótico na qualidade fisiológica de sementes de faveleira (Cnidoscolus juercifolius). Revista Brasileira de Engenharia Agrícola, v.9, n.1, p.66-72, 2005.

SOBRAL, M.; PROENÇA, C.; SOUZA, M.; MAZINE, F.; LUCAS, E. Myrtaceae: lista de espécies da Flora do Brasil. Rio de Janeiro: Jardim Botânico do Rio de Janeiro, 2015. Disponível em: http://floradobrasil.jbrj.gov.br. Acesso em: 10 fev. 2015.

VILLELA, F.A.; DONI-FILHO, L.; SEQUEIRA, E.L. Tabela de potenciais osmóticos em função da concentração de polietilenoglicol 6000 e da temperatura. Pesquisa Agropecuária Brasileira, v.26, p.1957-1968, 1991.

Revista Árvore, Viçosa-MG, v.40, n.4, p.649-660, 2016 
VIRGENS, I.O.; CASTRO, R.D.; FERNANDEZ, L.G.; PELACANI, C.R. Comportamento fisiológico de sementes de Myracrodruon urundeuva Fr. All. (Anacardiaceae) submetidas a fatores abióticos. Ciência Florestal, v.22, n.4, p.681-692, 2012. 